\title{
Differences in Repetitive Strength and Strength of Kicking a Ball between Soccer Players U14 and Children who are not Involved in Soccer
}

\author{
Boris Janjic ${ }^{1}$, Miroslav Smajic ${ }^{2}$, Bogdan Tomic ${ }^{3}$ and Milorad Jaksic ${ }^{2}$ \\ 'Primary School Luka Simonovic, Niksic, Montenegro, ${ }^{2}$ University of Novi Sad, Faculty of Sport and Physical Education, Novi Sad, Serbia, ${ }^{3}$ University \\ of Novi Sad, Faculty of Sport and Tourism, Novi Sad, Serbia
}

\begin{abstract}
The research is conducted with the aim of setting out the differences in repetitive strength of legs, torso, hands and shoulder girdle and strength of kicking a ball between soccer players U14 and children who are not involved in soccer. The sample consists of two groups of respondents. The first subsample group was comprised of 20 respondents of chronological age between $12.50 \pm 0.43$ who were actively involved in training process at soccer team Stars, and the other subsample included 20 respodents of chronological age between $12.50 \pm 0.62$ involved in system of Physical Education but who were not involved in training process of other sport branches. Canonical Discriminant Analysis within set of four motoric variables is used to determine the basic difference between groups and the contribution of each variable taken individually in overall discrimination groups. The sample of respondents who train soccer achieved better results in all applied tests. All tests showed statistical significance in discrimination of groups other than the test for assessing the strength of kicking a ball which is at the very margin of significance.
\end{abstract}

Key words: repetitive strength, strength of kicking a ball, differences, children

\section{Introduction}

The achievement of notable results in sports activities is conditioned by quality fitness preparedness, and the strength segment is certainly one of the most important. The dynamic strength, or the ability to develop muscular forces that enable the repetition of some simple movements related to lifting or shifting the weight of a load or body, or the ability to repeat the movement of the load or body, by overcoming resistance by isotonic muscle contractions is called repetitive strength (Nićin, 2000). Developing repetitive strength up to an optimum level makes adopting a wide array of technical-tactical elements and application of acquired skills and habits in a soccer game easier and of better quality. Determination of the initial condition for a more successful planning and programming of further training is significant for the development of repetitive strength in soccer (term endurance in strength is used in practice and literature). During the training process, current measurements are also important to give us information on whether the development takes place in the desired direction and the final measurements inform us about the level of ability that we have achieved through the training process.

A high-quality level of development of all strength segments is one of the basic preconditions for a successful realization of different demands of a soccer game. Repetitive strength is important for successful performance of all elements of a soccer game, primarily in securing a stable position of the standing leg, which allows manipulation of the ball with the other leg, then in passing the ball, receiving the ball, hitting the ball, dribbling and feinting, in jumps and hitting the ball with the head, change in direction of movement, in a duel game, as well as in creation of a kinetic chain of the swinging leg as a prerequisite for a stronger and more precise impact, i.e. in carrying out all technical-tactical elements of a soccer game with or without a ball, to a lesser or greater extent. The coefficient of inertia of repetitive strength is

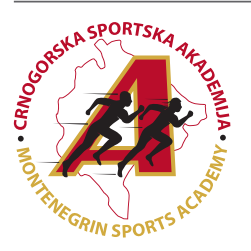

Correspondence: 
about 0.50 , which indicates that it can be significantly influenced through training (Dž. Idrizović \& K. Idrizović, 2001).

Physical fitness training should include situations arising from the soccer game itself (Bangsbo, 1994). This approach gives fitness training clear goals and we assume that the best training is situational training, the one most similar to the situation in the game. With modern soccer, more attention should be paid to training of the speed of action that resembles specific situations in the game (Bangsbo, 1994).

In this study, a segment of basic (repetitive strength) and specific motor functions (strength of kicking a ball) was examined. The entire motor space can be divided, according to the intensity and quality of the manifestation capability, into basic and specific. Basic motor skills are those that most people possess, and specific ones are created and developed through specific means, which is most common among athletes. Basic motor skills are the basis in every motor learning and represent the elementary value in the total area of human motoring. Specific motor skills are acquired and conditioned by the specificity of the training process of the sports branch (Bala, 2003). Specific motor functions include capabilities that directly affect the sporting result, since their structure, character and intensity of load are very close to the activities performed in competitions and show the biggest connection with the achieved sporting success (Malacko \& Radjo, 2004). Systematic training can significantly influence the development of specific physical abilities of fourteen-year-olds, permanently settled in the Mediterranean part of Montenegro (Bjelica, 2006). Research work found out that sprint and technical skills are the most discriminating variables for boys aged $\mathrm{U}-13$ and $\mathrm{U}-14$, while cardiorespiratory endurance is an important feature of boys aged U-15 and U-16 (Vaeyens et al., 2006). On the sample of 120 soccer players of cadet age, significant statistical differences in the strength of kicking a ball have been obtained after the preparatory period of six weeks (Gardasevic, Bjelica, \& Vasiljevic, 2017), while the sample of 122 respondents showed statistically significant differences between athletes and non-athletes (Kvesić, Brekalo, Crnjac, Katanić, \& Risteski, 2016).

Repetitive strength is in great positive correlation with precision (Rakočević, 1997). There is a high positive relationship between repetitive strength and speed and coordination, and especially with static strength, because they are regulated by the same mechanism in the CNS - the mechanism for regulating the duration of excitation (Kurelić et al., 1975).

This study aims to check the existence of difference between two groups of respondents in test segments of basic motor function estimation, within which the repetitive strength is assesed and the test for assesment of specific ability in soccer - the strength of kicking a ball. The aim of the study is to determine the differences between groups of respondents in the area of measured capabilities. In the difference analysis segment, the author is particularly interested in which variables contribute to the discrimination among the groups the most, and whether the training process or systematic training is responsible for the possible better development of measured potential of respondents belonging to the group of soccer players.

\section{Methods}

In terms of time determination, this research is of transversal character, and consists of one-time measurement of the corresponding indicators of basic-motor and specific skills of U14 soccer players. Regarding the degree of control, this scientific research belongs to the category of field research carried out in natural living conditions (Bala, 2007).

The sample of respondents who underwent research was derived from a male population of chronological aged between $12.50 \pm 0.62$ for those attending physical education classes and $12.50 \pm 0.43$ for respondents who train soccer, residing mainly in the city center of Niksic municipality. Respondents began testing on a voluntary basis with the consent of their parents since they are minors. For the purpose of informing, the purpose of the research as well as its significance were previously explained to both groups of respondents. Bearing in mind that according to the criterion of time determination this research is of transversal character, there was no significant drop out of the sample of respondents. The sample of respondents was divided into two groups according to the criteria for attending regular classes of physical education or additional training in the form of soccer training. The first sample consists of 20 boys who are actively involved in the training process in Soccer club Stars, and the second sample consists of 20 boys who are involved only in the process of physical education.

The group of respondents training soccer has been in the training process for 5 years \pm 6 months and has competed during two seasons in the selection of younger pioneers and pioneers at the republic level, in addition to attending physical education classes like the first group. During the weekly microcycle, they have three training units for a duration of 60 to 90 minutes, as well as a match for the duration of 60 minutes. The group of respondents not involved in the training process of any sports branch is involved in the physical education within the national programme, 3 times a week for 45 minutes. Within this research, the following measurement instruments were used: for estimating the repetitive strength of the arm and shoulder belt - Ground push-ups, for estimating the repetitive strength of the trunk - Lifting the trunk while lying on the back, for estimating the repetitive strength of legs - Squatts with a load of $10 \mathrm{~kg}$ and for evaluation of the strength of kicking a ball.

All tests were carried out in a gym, except for the test for estimating the strength of kicking a ball, which was realized at a soccer field. Tests were carried out by a team of surveyors made up of researchers and two meters, who are graduated professors of physical education. Previously, the meters specifically examined the standardization of the measuring instruments and were prepared for testing. Testing was done in the morning from $9 \mathrm{am}$ to $11 \mathrm{am}$. Tests were performed so that the previous test did not adversely affect the results in the next test, and the respondents had enough time to recover between tests. On the first day of testing, the abilities of the repetitive strength of legs were tested (Squatts with a load of $10 \mathrm{~kg}$ ) as well as the repetitive strength of the arm and shoulder belt (Ground push-ups) for both groups of respondents. On the second day, the abilities of the repetitive strength of the trunk (Lifting the trunk while lying on the back) were assessed as well as the test of the strength of kicking a ball.

The obtained survey data were processed using descriptive and comparative statistics. Arithmetic mean, standard deviation (Std.D.), standard arithmetic mean errors (Std.E.), minimum (MIN) and maximum MAX) result were all conducted within the descriptive statistics. When it comes to comparative statistics, a canonical discriminatory analysis was applied in order to obtain an image of the general difference between the groups of respondents and the individual contribution of each variable in general discrimination (the structure of the discriminatory function). 


\section{Results}

Based on the shown quantitative values of the central and dispersive statistics for both samples of respondents, it is noted that the average values of results in all tests are greater for re- spondents who train soccer, whose minimal and especially maximum test results are significantly higher than children who do not train soccer (Table 1).

Table 1. Central and dispersive statistics of respondents who train soccer and who do not train

\begin{tabular}{cccccc}
\hline variable & sample & Mean \pm Std.D. & Std.E. & min & max \\
\hline Ground push-ups & A & $8.4 \pm 2.7$ & 0.6 & 5 & 15 \\
(freq.) & B & $6.1 \pm 3.7$ & 0.8 & 1 & 15 \\
Lifting trunk while lying on & A & $39.8 \pm 7.6$ & 1.7 & 28 & 54 \\
back (freq.) & B & $22.3 \pm 9.3$ & 2.0 & 6 & 42 \\
Squatts with load of 10 kg & A & $61.7 \pm 22.3$ & 4.9 & 30 & 110 \\
(freq.) & B & $27.8 \pm 6.3$ & 1.4 & 18 & 40 \\
Strenght of kicking a ball & A & $27.1 \pm 4.1$ & 0.9 & 20 & 34 \\
(0.1 m) & B & $19.9 \pm 3.8$ & 0.8 & 14 & 28 \\
\hline
\end{tabular}

Legend: A - respondents involved in training process at soccer team Stars; B - respodents involved in system of Physical Education

The obtained results were further processed by Canonical Discriminant Analysis (Table 2), where a discriminating function was obtained with a significantly large canonical correlation coefficient $(\mathrm{Rc}=0.86)$. The applied method provides an overview of the general difference between the sample of respondents in the applied system of variables. In addition, the individual contribution of each variable in general discrimination of groups (the structure of a discriminative function) was calculated (Table 3).

Table 2. Results of canonical discriminatory analysis

\begin{tabular}{cccc}
\hline $\begin{array}{c}\text { Canonical } \\
\text { correlation }(\mathbf{R c})\end{array}$ & $\begin{array}{c}\text { Wilks' }^{\prime} \\
\text { Lambda }(\lambda)\end{array}$ & $\begin{array}{c}\text { Chi-square } \\
\left(\chi^{2}\right)\end{array}$ & Sig. \\
\hline 0.86 & 0.32 & 67.80 & 0.00 \\
\hline
\end{tabular}

The results in Table 2 indicate that the discriminatory strength of tests, shown by the Wilks'-Lambda test, is high (0.32), indicating that the differences between the respondents are statistically significant (Sig. $=0.00$ ). The canonical correlation coefficient $(\mathrm{Rc})$ indicates that the significance of the canonical function, i.e. the discriminativeness of the function, is explained with $86 \%$. The explained coefficient of correlation on the whole set of tests has a high value (Chi-square=67.80).
The results of the structure of the discriminative function show that the greatest contribution to the discriminative function are tests for the assessment of basic-motor abilities, in this case the specific repetitive strength of the muscle groups of the arm and shoulder belt, trunk and leg muscles, while the strenght of kicking a ball has not shown significant contribution to the discriminatory function (Table 3 ).

Table 3. Structure of discriminative function

\begin{tabular}{lc}
\hline \multicolumn{1}{c}{ Variable } & DF 1 \\
\hline Ground push-ups (freq.) & 0.47 \\
Lifting trunk into sitting position (freq.) & 0.39 \\
Squatts with load of $10 \mathrm{~kg}$ (freq.) & 0.34 \\
Strenght of kicking a ball $(0.1 \mathrm{~m})$ & 0.28 \\
\hline
\end{tabular}

\section{Discussion}

Based on the results shown, we can conclude that the obtained discriminatory factor (function) is statistically significant for the discrimination of groups of respondents in the area of applied variables (Sig. $=0.00$ ), which is also based on a very high coefficient of canonical correlation $(\mathrm{Rc}=0.86)$. The results of the arithmetic mean of the analyzed variables show that the sample of respondents who train soccer achieved better results in all applied tests. All tests showed statistical significance in discrimination of groups other than the test for assessing the strength of kicking a ball which is at the very margin of significance (0.28).

In variables for estimation of the repetitive strength of the arm and shoulder belt, the achieved difference is statistically significant, which indicates that this group of muscles is not neglected in the training process regardless of the specificity of the soccer game. We assume that the content structure of the training process in Soccer club Stars consists of strength pro- grammes aimed at the optimal development of all major muscular regions in order to balance them.

The sample of respondents who train soccer achieved better results in the muscle strength test of the abdominal wall. This can be explained by the significant role of the muscular region of the abdominal wall for the successful performance of technical elements in soccer. In relation to the obtained test results that measure the repetitive strength of the abdominal region of muscles, it is possible to assume that the difference between the groups in this variable is due to the training stimuli aimed at strengthening this muscular region as well as the impact of the stimulus of an intense soccer game.

The test for assessment of the repetitive strength of leg muscles is also a significant discriminator of the group of respondents. Children who train soccer have achieved statistically better results in this variable as well. The results obtained in this test can be said to be expected due to the reason of the dominance of the muscular region of the lower extremities in the 
realization of the movement tasks of a soccer game (passing the ball, kicking the ball, sprinting and changing running direction, dueling, jumping ...), which lead to a certain degree of hypertrophy of the current musculature. Such an affect certainly leads to a significant increase in strength as a motor skill, thus the conclusion that this was reflected in the better results of the respondents belonging to the group of soccer players. The poorer results of respondents who attend physical education classes can be interpreted as inadequate teaching, low frequency of classes, avoiding classes as well as a number of other disturbing factors.

The test for the assessment of the strength of kicking a ball lacked statistical significance in the difference between the groups, although it was at the very margin of significance with a coefficient of 0.28 . If we take a look at the arithmetic mean, as well as the minimum and maximum result of both groups of respondents, it is undisputed that boys who train soccer have achieved better results, but this did not lead to achieving statistical significance. An important condition for achieving good results in this test is the relation of explosive strength and soccer technique, which were not the subject of this study, where an explanation should be sought for the lack of statistically significant differences among the groups of respondents.

The mentioned differences between respondents in favour of soccer players can be attributed to the transformative processes of the training process. The assumption is that the training process decisively influenced the capabilities that defined the researched area and raised them to a higher level in the group of soccer players. The age of respondents is marked as a sensitive period for development of general endurance and dynamic strength endurance (Krsmanović, 1999; Nićin, 2000), and it is therefore assumed that the training process influenced the achieved differences in tested capabilities, through various movements, in favour of the respondents who train soccer. Study results of motor-functional abilities of children who are not engaged in sports activities and children who train soccer (Molnar, 1998) show a prominent difference in the level of repetitive strength in favour of children who train soccer. Successful players have better results in strength tests, flexibility, speed, aerobic endurance, anaerobic capacity and several technical skills than those less successful (Vaeyens et al., 2006). It has also been proven that differences in basic motor skills are in favour of boys attending a soccer school (Radosav et al., 2003). On the sample of 120 soccer players of cadet age, significant statistical differences in the strength of kicking a ball have been obtained after the preparatory period of six weeks, thus from this aspect I can ascertain the expected differences between soccer players and children who are not engaged in sports in the tests for the assessment of repetitive strength (Gardasevic, Bjelica, Vasiljevic, \& Milasinovic 2016). On a sample of 122 respondents, statistically significant differences were found between athletes and non-athletes in basic motor functions assessment tests (throwing medicine ball, long jump, high jump, plank, sprint at $100 \mathrm{~m}$, side-shifts, running with changing direction, and running at $400 \mathrm{~m}$ ), while the differences were not achieved in anthropometric variables (body height and body weight) and in flexibility assessment tests (Kvesić et al., 2016).

More broadly speaking, children's health is much better when they are involved in sports, and parents also evaluate the health of their children as much better. Children also benefit from participating in sports activities with regard to their overall performance in school and behavior in general (Felfe, Lechner, \& Steinmayr, 2016). The results of the same study on over 5000 respondents also provide evidence that the positive effects of sports in a club are partly explained by increased physical activity. Participating in sports clubs challenges children to take the initiative and plan, implement and achieve the set goal. Dealing with sports exposes children to working with other children in the team, which can make them better team players in other situations in life, and thus can explain the reduction of peer problems. Winning in competition can lead to a child's self-esteem, while defeat, despite possible negative effects on children's self-esteem, can teach them how to deal with such a situation.

Students who practice sports have good physical fitness and thus guarantee optimal conditions for proper growth. Adequate aerobic capacity reduces the risks of modern diseases such as diabetes, arteriosclerosis, hypertension, etc. Children who do not engage in sports due to poor general fitness often avoid physical activity, which threatens them to become more prone to physical deformities and the aforementioned diseases of today.

\section{Acknowledgements}

There are no acknowledgements.

\section{Conflict of Interest}

The authors declare that there are no conflicts of interest.

Received: 24 May 2018| Accepted: 17 August 2018| Published: 01 October 2018

\section{References}

Bala, G. (2003). Metodološki aspekti kinezioloških merenja sa posebnim osvrtom na merenja motoričkih sposobnosti. Ljubljana: Univerza v Ljubljani, Institut za kineziologiju fakulteta za šport.

Bala, G. (2007). Dizajniranje istraživanja u kineziologiji. Novi Sad: Fakultet sporta i fizičkog vaspitanja.

Bangsbo, J. (1994). Fitness Training in Soccer-A Scientific Approach. Bagsværd, Denmark: $\mathrm{HO}+$ Storm.

Bjelica, D.(2006). Sportski trening. Podgorica: Crnogorska sportska akademija.

Felfe C, Lechner M, Steinmayr A (2016) Sports and Child Development. PLoS ONE, 11(5), e0151729.

Gardasevic, J., Bjelica, D., \& Vasiljevic, I. (2017). The Strength of Kicking the Ball after Preparation Period with U15 Soccer Players. Sport Mont, 15(2), 39-42.

Gardasevic, J., Bjelica, D., Vasiljevic, I., \& Milasinovic, R. (2016). The Effects of the Training in the Preparation Period on the Repetitive Strength Transformation with Cadet Level Soccer Players. Sport Mont, 14(2), 31-33.

Idrizović, Dž. \& Idrizović, K. (2001). Osnovi antropomotorike. Podgorica: Univerzitet Crne Gore, Filozofski fakultet.

Krsmanović, B. (1999). Teorija i metodika fizičkog vaspitanja. Novi Sad: Univerzitet u Novom Sadu, Fakultet fizičke kulture.

Kurelić, N., Momirović, K., Stojanović, M., Šturm, J., Radojević, Š., \& ViskićŠtalec, N. (1975). Struktura i razvoj morfoloških i motoričkih dimenzija omladine. Beograd: Institut za naučna istraživanja Fakulteta za fizičko vaspitanje Univerziteta.

Kvesić, I., Brekalo, M., Crnjac, D., Katanić, N., \& Risteski, B. (2016) . Razlike u nekim antropološkim karakteristikama kod učenika sportaša i nesportaša. Zbornik radova "Sportske nauke i zdravlje", 6, 56-66.

Malacko, J. \& Rađo, I. (2004). Tehnologija sporta i sportskog treninga. Sarajevo: F.A.S.T.O.

Molnar, S. (1998). Morfološke karakteristike i motoričko-fumkcionalne sposobnosti dece koja treniraju fudbal i dece koja se ne bave sportom. Magistarski rad, Novi Sad: Fakultet sporta i fizičkog vaspitanja.

Nićin, Đ. (2000). Antropomotorika-teorija. Novi Sad: Univerzitet u Novom Sadu, Fakultet fizičke kulture.

Radosav, R., Molnar, S. \& Smajić, M. (2003). Teorija i metodika fudbala. Novi Sad: Univerzitet u Novom Sadu, Fakultet fizičke kulture.

Rakočević, T. (1997). Korelacija nekih motoričkih dimenzija kod fudbalera početnika. Fizička kultura, (1-2), 40-49.

Vaeyens, R., Malina, R.M., Janssens, M., Van Renterghem, B., Bourgois, J., Vrijens, J. \& Philippaerts, R.M. (2006) A multidisciplinary selection model for youth soccer: The Ghent Youth Soccer Project. British Journal of Sports Medicine, 40, 928-934. 